\title{
Effect of Gibberellin on Some Fatty Acid Profiles Under Nitrogen Starvation in Green Algae Chlorella vulgaris
}

\author{
Uygar Kabaoglu ${ }^{\circledR 1}$, Ufuk Mehmet Aslan ${ }^{\circledR 2}$, Dilek Unal ${ }^{\circledR 1,3, *}$
}

${ }^{1}$ Biotechnology Application and Research Center, Bilecik Seyh Edebali University, Bilecik, Turkey ${ }^{2}$ Department of Chemistry, Faculty of Science and Arts, Mersin University, Mersin, Turkey

${ }^{3}$ Department of Molecular Biology and Genetic, Faculty of Sciences and Arts, Bilecik Seyh Edebali University, Bilecik, Turkey

\begin{abstract}
Plant growth substances could be stimulating algal growth rate and alter lipid compositions. In the present study, we tested hypothesis that exogenous gibberellin (GA) has any effect on growth rate and some fatty acid profiles in green algae Chlorella vulgaris. In Bold Basal Medium with $100 \mu \mathrm{M}$ $\mathrm{GA}_{3}$, cell density increased to $68.57 \%$ on third day as compared to the control cells. These results indicated that $\mathrm{GA}_{3}$ enhanced microalgal growth and cell size. The lipid profile was also altered compared to control using Gas Chromatography-Mass Spectrometry (GC-MS). GA 3 promotes the production of C16:0, C18:0, C18:1 and C18:3 on day-3 and-5. Under nitrogen starvation condition, application of $\mathrm{GA}_{3}$ provide enhanced algae growth and stimulated C16:0 and C18:1 production. In conclusion, this study demonstrated that gibberellin could be a good candidate as a hormone for increasing lipid production in microalgae culture system.
\end{abstract}

\section{ARTICLE HISTORY}

Received: May 19, 2020

Revised: November 02, 2020

Accepted: February 22, 2021

\section{KEYWORDS}

Chlorella vulgaris,

Gibberellin,

GC-MS,

Fatty acid,

Nitrogen starvation

\section{INTRODUCTION}

Microalgae are photosynthetic microorganisms with a high growth rate and the ability to convert carbon dioxide into biomass. Microalgae can synthesize high levels of metabolites that play an important role in biodiesel production, such as docosahexaenoic acid (DHA), eicosapentaenoic acid (EPA), carotenoids ( $\beta$-carotene, lutein and astaxanthin), and phycocyanin (Mata et al., 2016). In this respect, it is widely accepted today as a potential sustainable biomass raw material source for biofuel production (Borowitzka \& Moheimani, 2013). Although microalgae are a rich source of potential molecules (such as lipids, carbohydrates and proteins) that can be converted into fuel substitutes that are renewable, nontoxic, biodegradable and carbon-neutral; therefore, they are regarded as an environmentally friendly fuel source (Dillschneider et al., 2013), microalgal biofuels are still not seen as an alternative to fossil fuels. Because the main obstacle to successfully implementing microalgal biofuels as a replacement for fossil fuels is their high cost to produce. Today, many researchers focused on obtaining cheaper and high efficiency microalgal biofuels.

CONTACT: Dilek Unal $₫$ dilek.unal@bilecik.edu.tr $\equiv$ Department of Molecular Biology and Genetic, Faculty of Sciences and Arts, Bilecik Seyh Edebali University, Bilecik, Turkey 
The manipulation of culture conditions or genetic engineering approaches are widely used to increase targeted compounds such as lipids, pigments, proteins and PUFAs from microalgae (Sreekumar et al., 2018). One of the most widely used approaches is enhanced the cultivation of microalgae or biomass production. This approach is the most expensive and technically difficult step in the implementation of algae biofuel production (Leite et al., 2013). Increasing the biomass productivity and/or lipid and carbohydrate production of microalgae can increase algae cultivation's economic feasibility (Abdelaziz et al., 2013). The cellular accumulation of lipids in microalgae can also be induced by different environmental factors such as high light and salinity (Solovchenko et al., 2008; Rodolfi et al., 2009; Ren et al., 2014; Benvenuti et al., 2015). Previous studies demonstrated that application of metal stress such as copper, magnesium, iron and cadmium enhanced total lipid content (Liu et al., 2008; Li et al., 2013; Ren et al., 2014). It has also known that $\mathrm{N}$-starvation causes alternation on carbon flux through the pathway of protein synthesis to lipid and/or carbohydrate metabolisms (James et al., 2013; Li et al., 2013; Jerez et al., 2016). Thus, high lipid accumulation in microalgae can be occurring under N starvation (Rodolfi et al., 2009; Benvenuti et al., 2015). Previous studies demonstrated that lipid content enhanced a 2 to 4 -fold under N-starvation in microalgae such as Chlorella, Chlamydomonas, Dunaliella and Nannochloropsis species (Rodolfi et al., 2009; Cakmak et al., 2012; Illman et al., 2000). However, algae growth, development and metabolism effected negatively under nitrogen starvation.

Exogenously applying of plant growth regulators could be one of the alternative strategies to stimulate the synthesis fatty acids (Park et al., 2013; Lu \& Xu, 2015). Some research groups reported that auxin and jasmonic acid altered to fatty acid composition in Chlorella species (Jusoh et al., 2015 ; 2015 ). Gibberellins (GAs) are diterpenoid acids that affect many areas of plant growth, such as leaf growth and flower and seed development. They promote stem elongation, fruit generation and seed germination in higher plant (Nakajima et al., 2006). It has also known that gibberellins found in macro-and microalgae ( $\mathrm{Lu} \mathrm{\&} \mathrm{Xu,} \mathrm{2015).} \mathrm{Previous} \mathrm{studies}$ demonstrated that active GAs, $\mathrm{GA}_{1}$ and $\mathrm{GA}_{3}$ in brown algae Fucus vesiculosus and $F$. spiralis (Radley, 1961; Jennings, 1968). Additionally, many studies have focused on gibberellin's effect on the growth of microalgae and their bioproducts. In addition, previous studies have reported that GA increases biomass accumulation and triacylglycerol content in microalgae (Mekhalfi et al., 2014; Du et al., 2015). Although increased growth in response to GAs has been documented in some algae (Jennings, 1968; Joseph \& Chennubhotla, 1999), little evidence for GAs activity on growth and developmental processes has been observed in green algae (Lu \& $\mathrm{Xu}, 2015)$. Moreover, the effects of $\mathrm{GA}_{3}$ under normal conditions and $\mathrm{N}$-starvation on fatty acid production have not demonstrated yet. In the present work, we tested two hypotheses; (i) exogenously $\mathrm{GA}_{3}$ altered fatty acid composition under normal conditions, (ii) exogenous $\mathrm{GA}_{3}$ changes the fatty acids composition) under $\mathrm{N}$-starvation.

\section{MATERIAL and METHODS}

\subsection{Culture Conditions}

Chlorella vulgaris was obtained from the EGEMAC culture collection, Ege University, Izmir, Turkey. Five of the $250 \mathrm{~mL}$ Erlenmeyer flasks of $C$. vulgaris were used for the experiment. All experiments were carried out using cells in the exponential phase. It set up four different experimental group. The first group was the culture that was grown in a Bold Basal media (BBM, as a control). The second group was $250 \mathrm{~mL}$ Erlenmeyer flask of C. vulgaris grown in a BBM containing $100 \mu \mathrm{M} \mathrm{GA}_{3}$. Third group was that $C$. vulgaris culture was collected with centrifuge and grown in BBM without any nitrogen sources. Finally, fourth group was that $C$. vulgaris culture was grown in BBM without nitrogen and with $\mathrm{GA}_{3}$ in a growth chamber under continuous illumination at $80 \mu \mathrm{mol} \mathrm{m} \mathrm{m}^{-2}$ light intensity and $24{ }^{\circ} \mathrm{C}$ for $1,3,5$ and 7 days. 


\subsection{Growth Rate and Cell Size}

The absorbance of cell growth was measured on UV-spectrophotometer at $663 \mathrm{~nm}$, and cell number was counted with Neubauer hemocytometer. Each experiment repeated three times.

\subsection{Methyl Esters of Fatty Acids (FAMEs)}

FAMEs were carried out according to the modified procedure of Bligh and Dyer (1959) and Kattner and Fricke (Kattner \& Fricke, 1986). Briefly, the extraction mixture with the dissolved lipids was evaporated to dryness and trans-esterified with $2 \mathrm{~mL}$ of $3 \% \mathrm{H}_{2} \mathrm{SO}_{4}$ in methanol (Kattner \& Fricke, 1986) four hours at $70^{\circ} \mathrm{C}$. After cooling to room temperature, 2 $\mathrm{mL}$ of hexane was added for extraction of FAMEs. The solvent was evaporated, and $50 \mu \mathrm{L}$ of hexane was added. Each experiment repeated three times.

\subsection{GC-MS Analysis}

The methyl esters of fatty acids were quantified by a gas chromatograph (Shimadzu QP2010 ultra model) equipped with a flame ionization detector (FID). The GC-MS column (TRB-5MS model) was fused $30 \mathrm{~mm} \times 0.25 \mathrm{~mm} \times 0.25 \mu \mathrm{m}$. Injector and FID inlet temperature were $270^{\circ} \mathrm{C}$ and $250^{\circ} \mathrm{C}$, respectively. Column temperature was programmed to hold at $40^{\circ} \mathrm{C}$ for $4 \mathrm{~min}$, then rise at $8^{\circ} \mathrm{C} \mathrm{min}^{-1}$ increase to $280^{\circ} \mathrm{C}$ and was held at this temperature for $20 \mathrm{~min}$. The column head pressure of carrier gas (helium) was flow rate $0.8 \mathrm{~mL} \mathrm{~min}^{-1}$. Each experiment repeated three times.

\subsection{Statistical Analysis}

Statistical analysis was performed with one-way analysis of variance (ANOVA) or Student's t-test followed by post-hoc Tukey test as appropriate (SPSS for Windows, version 11.0).

\section{RESULTS and DISCUSSION}

\subsection{Effect of Gibberellin on Cell Growth and Size}

Exogenously plant growth regulators induced cell growth and algal biomass in microalgae (Joseph \& Chennubhotla, 1999). GAs is a phytohormone and essential for plant growth and development processes (Sasaki et al., 2003; Tyler et al., 2004). In the present study, the stimulation effect of $\mathrm{GA}_{3}$ on the growth was tested depend on time (Table 1). As shown in Table 1 , the cell density of $C$. vulgaris at early stationary growth phase was $4.92 \times 10^{6} \pm$ cells/mL. In BBM with $100 \mu \mathrm{M} \mathrm{GA}_{3}$, cell density increased to $9.74 \times 10^{6} \pm$ cells $/ \mathrm{mL}$ on third day. The cell density also increased $127.99 \%$ on the seventh day as compared to the control cells (Table 1). Previous studies demonstrated that GA3 stimulated biomass production in Chlamydomonas reinhardtii (Park et al., 2013). Falkowska et al. (2011) also showed GA3 had a stimulating influence on the cell number in C. vulgaris. Similarly, it was observed that GA treatment increased biomass productivity by 8.7 -fold and 5.3-fold, respectively, in $C$. ellipsoidea and Scenedesmus abundans (González-Garcinuño et al., 2016). In this study, microscopic analysis in the present study showed that application of GA 3 significantly affected cell size in $C$. vulgaris culture (Table 1 ). These results indicated that $\mathrm{GA}_{3}$ could be a very useful phytohormone for improving algal cell density. Similarly, Yu et al. (2016) reported that an increase in growth/biomass due to GA treatment might increase glucose uptake rate. Still, this consumption may occur with inhibition of glycolysis and the tricarboxylic acid cycle. However, more studies are needed to determine which gibberellins promote metabolic pathways.

\subsection{Effect of Gibberellin on Fatty Acid Composition}

Previously studies reported that plant growth regulators and growth stage altered oil compositions in microalgae and higher plants (Joseph \& Chennubhotla, 1999; Lu \& Xu, 2015). In the normal conditions, our results demonstrated that production of C18:0 increased on the 
first and third days; however, interestingly, the increased amount of C16:0, C18:1, and C18:3 occurs especially on fifth day (Figure 1) under normal conditions. Grindstaff et al. (1996) demonstrated that $\mathrm{GA}_{3}$ stimulates the degree of unsaturation of fatty acid in barley aleuronic layers in the higher plant. Gozález-Garcinuňo et al. (2016) also demonstrated the application of Gibberellins enhanced lipid productivity in C. ellipsoidea. In addition, treatment with $\mathrm{GA}_{3}$ induced the amount of polyunsaturated fatty acid (especially, C18:2, and C18:3) and decreased the amount of saturated (16:0 and 18:0) fatty acid in isolated ER microsomal membranes (Grindstaff et al., 1996). In contrast, in the present study, GA3 enhanced the production of C18:0, C18:1 and C16:0 on the first day and up to maximum production on the fifth day $(p<0.05$, Figure 2). These results indicated that application of gibberellin significantly enhanced fatty acid production in algae.

Table 1. The growth parameter of Chlorella vulgaris culture applied with $\mathrm{GA}_{3}$ or control

\begin{tabular}{|c|c|c|c|c|c|c|}
\hline \multirow[b]{2}{*}{$\begin{array}{l}\text { Days after } \\
\text { treatment }\end{array}$} & \multicolumn{2}{|c|}{ Cell density } & \multirow{2}{*}{$\begin{array}{l}\text { Cell density } \\
\% \text { relative to } \\
\text { control }\end{array}$} & \multicolumn{2}{|c|}{ Cell Size $(\mu \mathrm{m})$} & \multirow{2}{*}{$\begin{array}{c}\text { Cell size \% } \\
\text { relative to } \\
\text { control }\end{array}$} \\
\hline & $\begin{array}{c}\text { Control } \\
\mathrm{X} \pm \mathrm{SD}\end{array}$ & $\begin{array}{c}\mathrm{GA}_{3} \\
\mathrm{X} \pm \mathrm{SD}\end{array}$ & & $\begin{array}{c}\text { Control } \\
\mathrm{X} \pm \mathrm{SD} \\
\end{array}$ & $\begin{array}{c}\mathrm{GA}_{3} \\
\mathrm{X} \pm \mathrm{SD}\end{array}$ & \\
\hline 1.day & $4.92 \times 10^{6} \pm 0.14$ & $5.33 \times 10^{6} \pm 0.18^{c}$ & $108.33 \%$ & $2.92 \pm 0.43$ & $3.17 \pm 0.58$ & $8.56 \%$ \\
\hline 3.day & $7.61 \times 10^{6} \pm 0.12^{\mathrm{a}}$ & $9.74 \times 10^{6} \pm 0.30^{\mathrm{bc}}$ & $127.99 \%$ & 0.63 & $3.05 \pm 0.54$ & $15.53 \%$ \\
\hline 5.day & $14.20 \times 10^{6} \pm 0.21^{\mathrm{a}}$ & $18.54 \times 10^{6} \pm 0.21^{\mathrm{bc}}$ & $130.56 \%$ & $2.93 \pm 0.62$ & $2.95 \pm 0.60$ & $0.68 \%$ \\
\hline 7.day & $16.07 \times 10^{6} \pm 0.28^{a}$ & $22.45 \times 10^{6} \pm 0.90^{\mathrm{bc}}$ & $139.7 \%$ & $2.65 \pm 0.43$ & $3.01 \pm 0.56$ & $13.58 \%$ \\
\hline
\end{tabular}

"a" is a significant value when compared to control 1-day, "b" is a significant value when compared to GA3 1-day, and "c" is a significant value when compared to control.

Figure 1. Fatty acid profile of Chlorella vulgaris grown under normal culture condition.
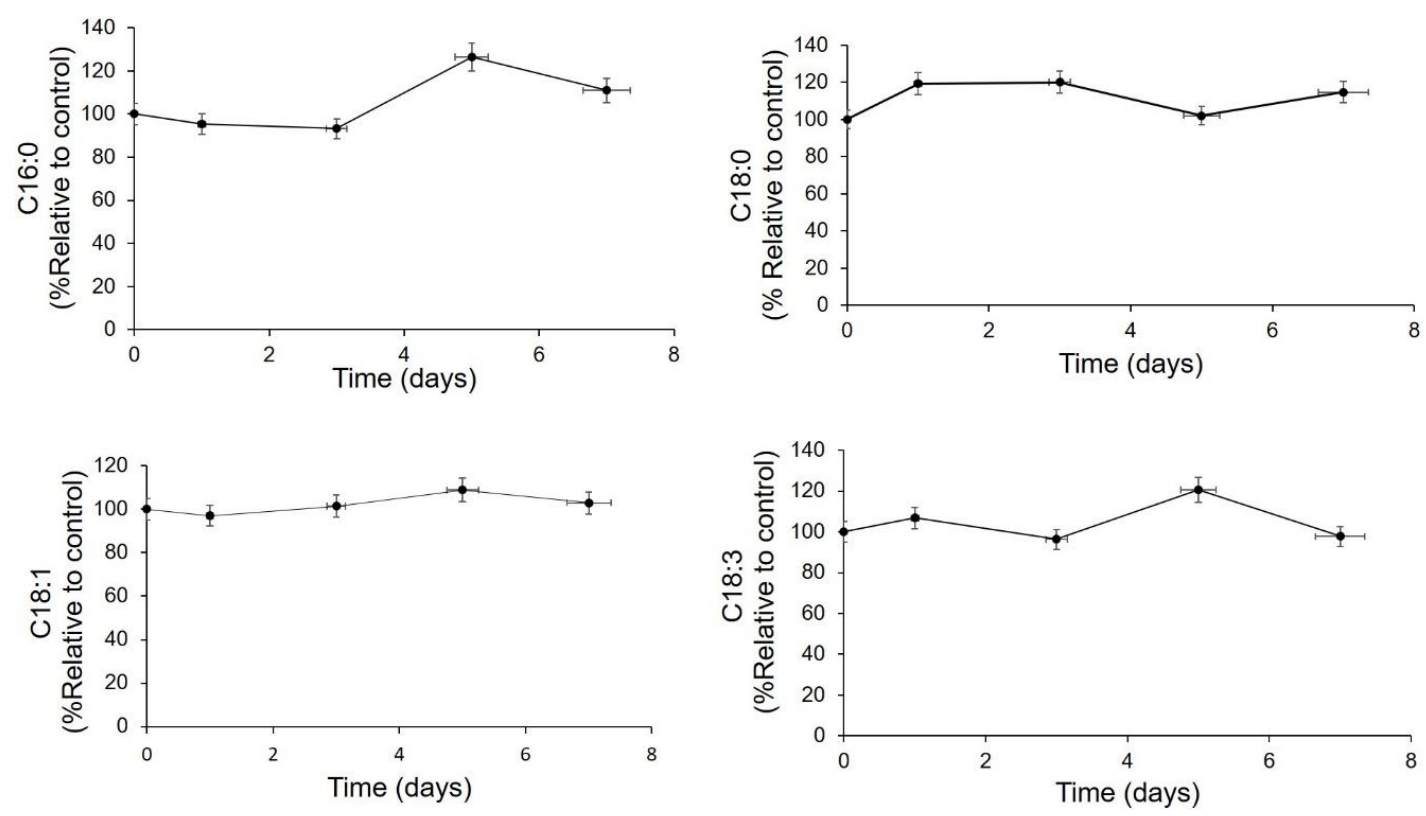

\subsection{Effect of Gibberellin on Growth and Fatty Acid Composition Under N-Starvation}

Effect of $\mathrm{N}$-starvation on microalgae growth rate was demonstrated as seen in Table 2. Zhu et al. (2014) reported that N-starved cells increased twofold in number within the first two days. Similarly, our results showed that cell density of $C$. vulgaris increased 2-fold within three days under $\mathrm{N}$-depletion (Table 2). It could be used for nitrogen storage during growth processes. However, cell density decreased up to approximately 1.66-fold in day-7 when compared to day3. Application of $\mathrm{GA}_{3}$ provides to increasing to cell growth under $\mathrm{N}$-starvation (Table 2). After 
5 days, the cell growth started to decrease because of the lack of nitrogen sources. This effect could be explained that gibberellin as a phytohormone could trigger some metabolic pathways which are involved in response to nitrogen starvation. On the other hand, this hypothesis is speculation and needs to be testing in future studies.

Table 2. The growth parameter of Chlorella vulgaris culture applied with $\mathrm{GA}_{3}$ or control

\begin{tabular}{cccc}
\hline $\begin{array}{c}\text { Days after } \\
\text { treatment }\end{array}$ & $\begin{array}{c}\text { N-starvation } \\
\mathrm{X} \pm \mathrm{SD}\end{array}$ & $\begin{array}{c}\text { Cell density } \\
\mathrm{N} \text {-starvation GA } \\
\mathrm{X} \pm \mathrm{SD}\end{array}$ & $\begin{array}{c}\text { Cell density } \\
\% \text { relative to N- } \\
\text { starvation }\end{array}$ \\
\hline 1.day & $4.67 \times 10^{6} \pm 0.12$ & $4.83 \times 10^{6} \pm 0.05$ & $103.43 \%$ \\
3.day & $9.33 \times 10^{6} \pm 0.16^{\mathrm{a}}$ & $11.29 \times 10^{6} \pm 0.12^{\mathrm{bc}}$ & $121.01 \%$ \\
5.day & $7.51 \times 10^{6} \pm 0.25^{\mathrm{a}}$ & $14.02 \times 10^{6} \pm 0.18^{\mathrm{bc}}$ & $186.68 \%$ \\
7.day & $6.63 \times 10^{6} \pm 0.09^{\mathrm{a}}$ & $12.06 \times 10^{6} \pm 0.09^{\mathrm{bc}}$ & $181.9 \%$ \\
\hline
\end{tabular}

"a" is significant value when compared to control 1-day, "b" is significant value when compared to $\mathrm{GA}_{3} 1$-day, and "c" is significant value when compared to control.

Figure 2. Fatty acid profile of Chlorella vulgaris grown under normal culture condition with $100 \mu \mathrm{M}$ $\mathrm{GA}_{3}$
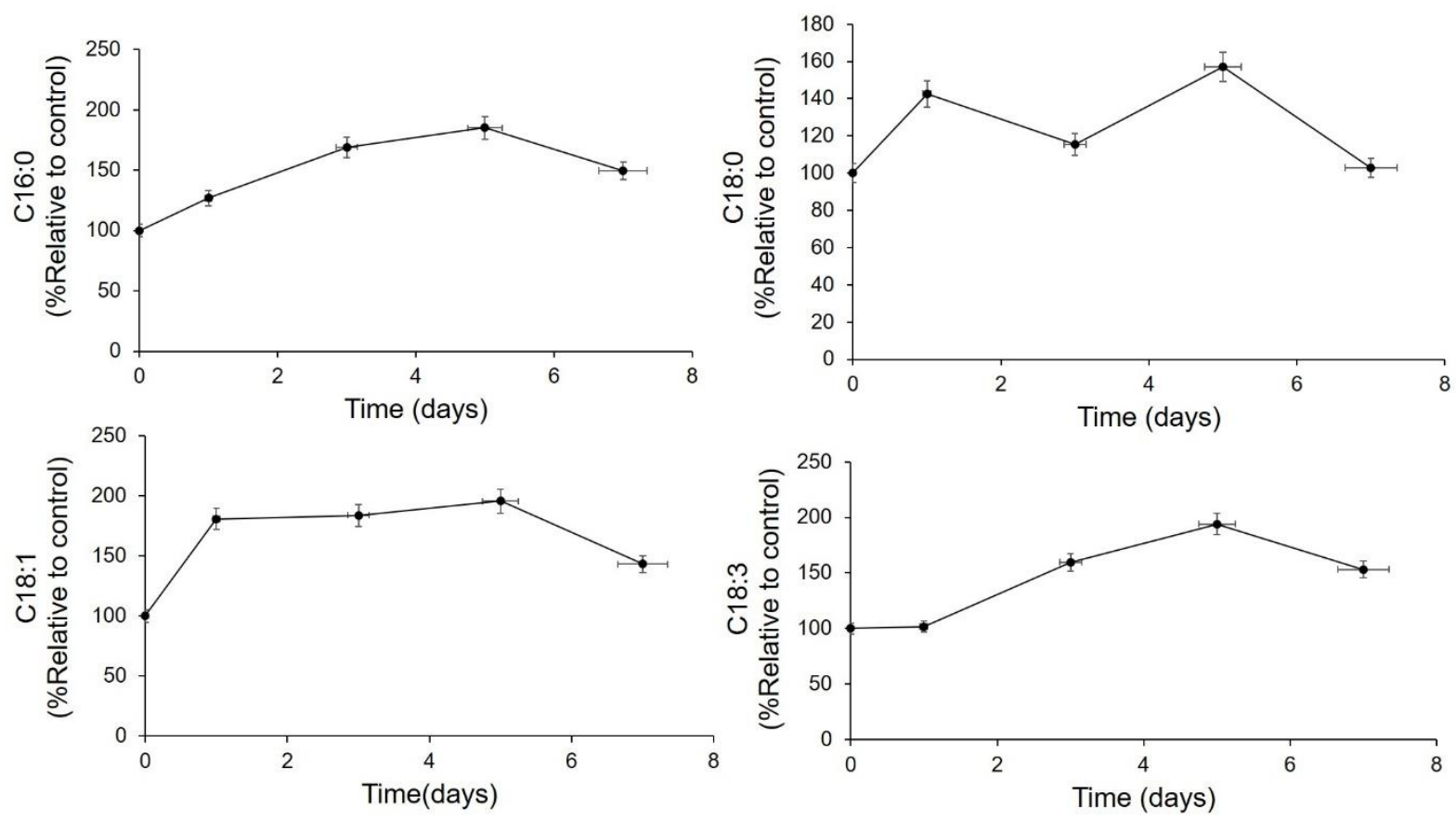

$\mathrm{N}$-starvation is very a general approach for changing fatty acid composition in algae. Previous studies demonstrated that $\mathrm{N}$-starvation induced fatty acid production especially $\mathrm{C}$ 16:0 and C18:1 in microalgae (Benvenuti et al., 2015; Babu, Wu, Kabra \& Kim, 2017). In the present study, the fatty acid profile changed under $\mathrm{N}$-starvation. The $\mathrm{C} 16: 0$ and $\mathrm{C} 18: 1$ increased within the first day under N-depletion (Figure 3). However, C18:3 and C18:0 profile in C. vulgaris significantly decreased after 3 days (Figure 3). Babu et al. (2017) demonstrated that phytohormone's application under N-limitation is a useful cultivation strategy to improve the lipid production rate of microalgae. Similarly, application of $\mathrm{GA}_{3}$ with N-starvation significantly increased C16:0, C18:0, C18:1, and C18:3 at first and three days $(\mathrm{p}<0.01$, Figure 4). Our results also showed that the application of $\mathrm{GA}_{3}$ under normal conditions provided approximately 1.02, 1.18, 1.24 and 1.16 fold higher results C18:0, C18:1, C18:3 and C16:0 
compared to N-starvation with GA3 within 3 days, respectively (Figure 4). This study showed that other combinations of growth medium supplement with $\mathrm{GA}_{3} 100 \mu \mathrm{M}$ and one or more published strategies such as nitrogen starvation could further increase the unsaturated fatty acid synthesis productivity of $C$. vulgaris, making its use industrially viable.

Figure 3. Fatty acid profile of Chlorella vulgaris grown under N-starvation condition.
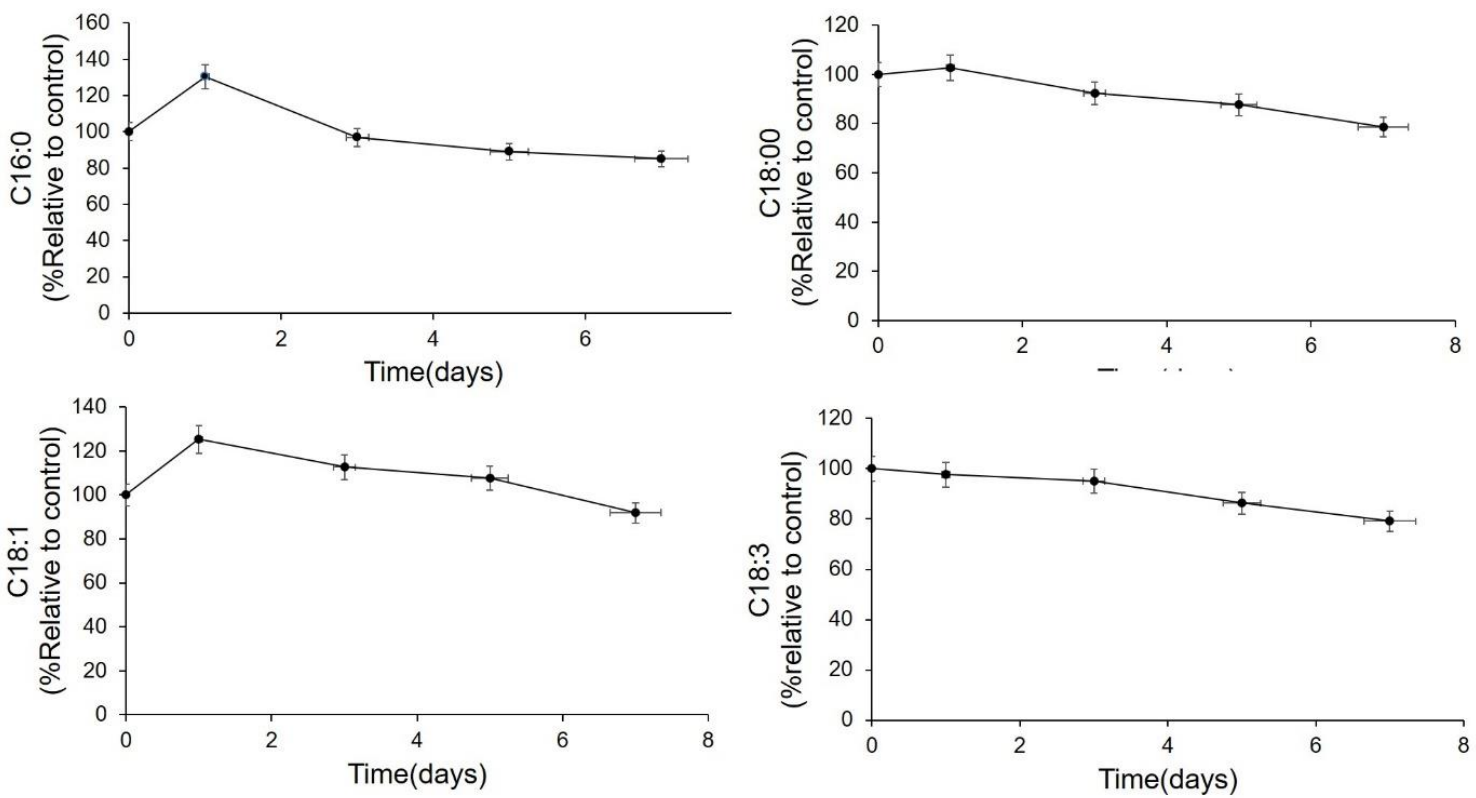

Figure 4. Fatty acid profile of Chlorella vulgaris grown under N-starvation condition with $100 \mu \mathrm{M} \mathrm{GA} 3$
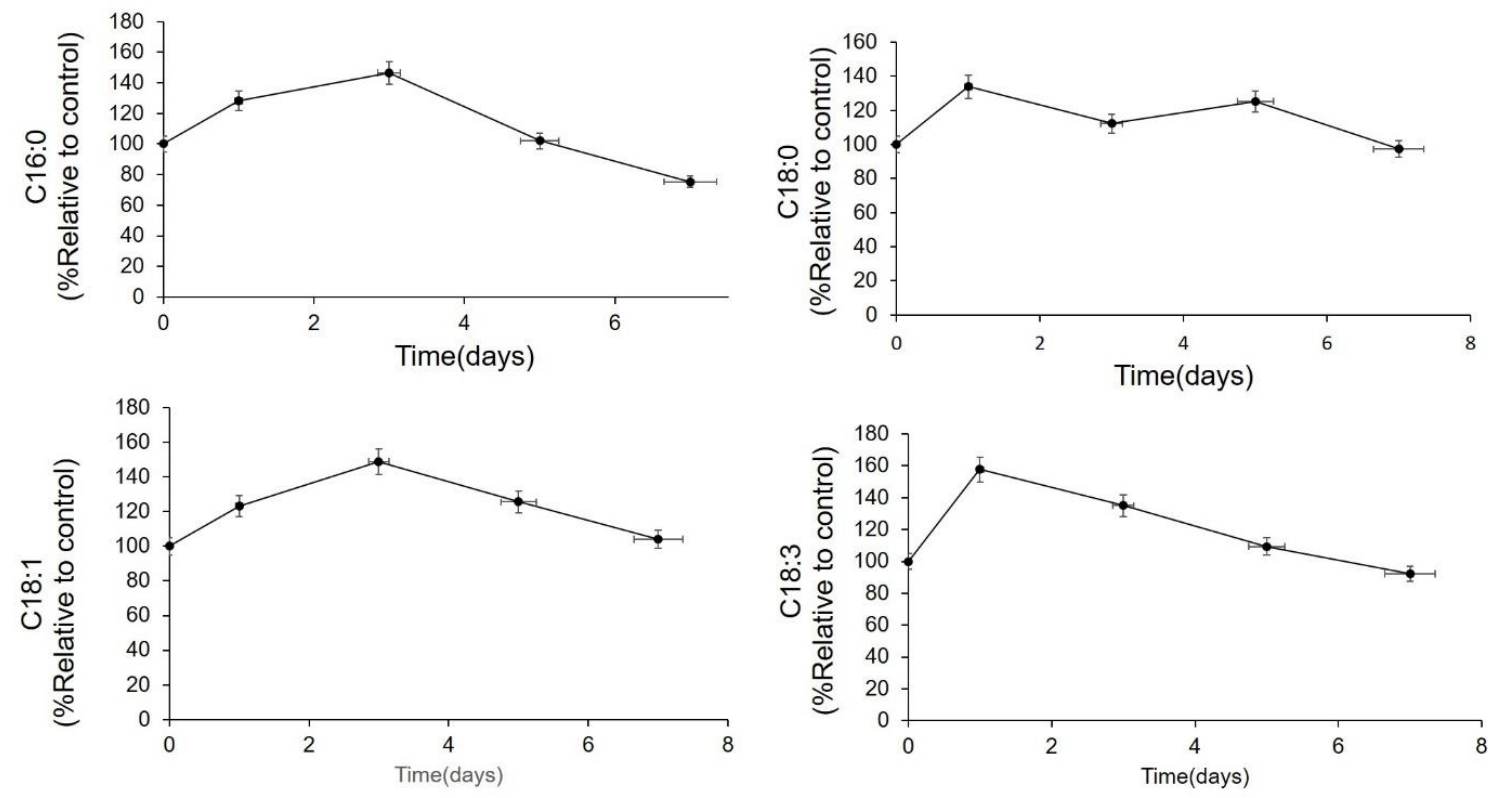

\section{CONCLUSION}

The combination of plant growth regulators and abiotic stress is a general approach for enhanced the accumulation of fatty acids and maintaining the microalgal biomass. In the present study, our results indicate that $\mathrm{GA}_{3}$ supplementation increased microalgal growth rate, algal cell size and lipid production especially involved in biodiesel production under nitrogen starvation. These results showed the potential of application $\mathrm{GA}_{3}$ in algal culture as a utilizer 
for biodiesel application. This data also demonstrated that gibberellin could play a role in response to stress in algae physiology. In addition, the use of Gibberellic acid can bring us one step closer to making $C$. vulgaris suitable for biodiesel production. This study proposes using plant regulators to increase unsaturated fatty acids in combination with different stress conditions and help develop growing strategies for higher microalgal biodiesel production. Therefore, it seems necessary to study this subject in future research to create ideal culture conditions for biodiesel production.

\section{Acknowledgements}

We thanks to 2209 undergraduate student project of Scientific and Technological Research Council of Turkey (TUBITAK).

\section{Declaration of Conflicting Interests and Ethics}

The authors declare no conflict of interest. This research study complies with research publishing ethics. The scientific and legal responsibility for manuscripts published in IJSM belongs to the author(s).

\section{Authorship contribution statement}

Uygar Kabaoglu: Investigation, Microscopic studies, Analysis of fatty acid. Ufuk M. Aslan: Cell growth, Fatty acid analysis. Dilek Unal: Experimental design, Writing-orginal draft, Statistical analysis, supervision.

\section{Orcid}

Uygar Kabaoglu (D) https://orcid.org/0000-0002-6602-8570

Ufuk M. Aslan (D) https://orcid.org/0000-0003-0743-9801

Dilek Unal (D) https://orcid.org/0000-0002-6915-9699

\section{REFERENCES}

Abdelaziz, A.E.M., Leite, G.B., \& Hallenbeck, P.C. (2013) Addressing the challenges for sustainable production of algal biofuels: I. Algal strains and nutrient supply. Environ. Technol., 34, 1783-1805. https://doi.org/10.1080/09593330.2013.827748

Babu, G.A., Wu, X., Kabra, A.N., \& Kim, D P. (2017). Cultivation of an indigenous Chlorella sorokiniana with phytohotmones for biomass and lipid production under N-limitation. Algal Res., 23, 178-185. https://doi.org/10.1016/j.algal.2017.02.004

Benvenuti, G., Bosma, R., Cuaresma, M., Janssen, M., Barbosa, M.J., \& Wijffels, R.H. (2015). Selecting microalgae with high lipid productivity and photosynthetic activity under nitrogen starvation. J. Appl. Phycol., 27,1425-1431. https://doi.org/10.1007/s10811-0140470-8

Bligh, E.G., \& Dyer, W.J. (1959). A rapid method of total lipid extraction and purification. Canadian J. Biochem. Physiol., 37(8), 911-917. https://doi.org/10.1139/o59-099

Borowitzka, M.A., \& Moheimani, N.R. (2013) Sustainable biofuels from algae. Mitig. Adapt. Strateg. Glob. Change, 18, 13-25. https://doi.org/10.1007/s11027-010-9271-9

Cakmak, T., Angun, P., Demiray, Y.E., Ozkan, A.D., Elibol, Z., \& Tekinay, T. (2012). Differential effects of nitrogen and sulfur deprivation on growth and biodiesel feedstock production of Chlamydomonas reinhardtii. Biotechnol. Bioeng., 109, 1947-1957. https://doi.org/10.1002/bit.24474

Dillschneider, R., Steinweg, C., Rosello-Sastre, R., \& Posten, C. (2013). Biofuels from microalgae: photoconversion efficiency during lipid accumulation. Bioresour. Technol., 142, 647-654. https://doi.org/10.1016/j.biortech.2013.05.088 
Du, K., Tao, H., Wen, X., Geng, Y. \& Li, Y. (2015). Enhanced growth and lipid production of Chlorella pyrenoidosa by plant growth regulator GA3. Fresenius Environ. Bull., 24, 3414-3419.

Falkowska, M., Pietryczuk, A., Piotrowska, A., Bajguz, A., Grygoruk, A., \& Czerpark, R. (2011). The effect pf gibberellic acid $\left(\mathrm{GA}_{3}\right)$ on growth, metal biosorption and metabolism of the green algae Chlorella vulgaris (Chlorophyceae) Beijerinck exposed to cadmium and lead stress. Polish J. Environ. Stud., 20(1), 53-59.

González-Garcinuño, A., Sánchez-Álvarez, J.M., Galán, M.A., \& Martin del Valle, E.M. (2016). Understanding and optimizing the addition of phytohormones in the culture of microalgae for lipid production. Biotechnol. Prog., 32, 1203-1211. https://doi.org/10.1002/btpr.2312

Grindstaff, K.K., Feilding, L.A., \& Brodi, M.R. (1996). Effect of Gibberellins and heat shock on the lipid composition of Endoplasmic reticulum in Barley Aulorene layers. Plant Physiol., 110, 571-581. https://doi.org/10.1104/pp.110.2.571

Illman, A.M., Scragg, A.H., \& Shales, S.W. (2000). Increase in Chlorella strains calorific values when grown in low nitrogen medium. Enzyme Microb. Tech., 27, 631-635. https://doi.org/10.1016/s0141-0229(00)00266-0

James, G.O., Hocart, C.H., Hillier. W., Price, G.D., \& Djordjevic, M.A. (2013). Temperature modulation of fatty acid profiles for biofuel production in nitrogen deprived Chlamydomonas reinhardtii. Bioresour. Technol., 127, 441-447. https://doi.org/10.1016/j.biortech.2012.09.090

Jennings, R.C. (1968). Gibberellins as Endogenous growth regulators in green and brown algae. Planta, 80, 34-42.

Jerez, C.G., Malapascua, J.R., Sergejevová, M., Figueroa, F.L., \& Masojidek, J. (2016). Effect of Nutrient Starvation under High Irradiance on Lipid and Strach Accumulation in Chlorella fusca (Chlorophyta). Mar. Biotechnol., 18, 24-36. https://doi.org/10.1007/s10126-015-9664-6

Joseph, I., \& Chennubhotla, V.S.K. (1999). Gibberellic acid and 2,4-D as growth regulators in laboratory culture of seaweeds. Indian J. Mar.Sci., 28, 66-69.

Jusoh, M., Loh, S.H., Chuah, T.S., Aziz, A., \& Cha, T.S. (2015). Indole-3-acetic acid (IAA) induced changes in oil content, fatty acid profiles and expression of four fatty acid biosynthetic genes in Chlorella vulgaris at early stationary growth phase. Phytochemistry, 111, 65-71. https://doi.org/10.1016/j.phytochem.2014.12.022

Jusoh, M., Loh, S.H., Chuah, T.S., Aziz, A., \& Cha, T.S. $\left(2015^{\mathrm{b}}\right)$. Elucidating the role of jasmonic acid in oil accumulation, fatty acid composition and gene expression in Chlorella vulgaris (Trebouxiophyceae) during early stationary growth phase. Algal Res., 9, 14-20. https://doi.org/10.1016/j.algal.2015.02.020

Kattner, G., \& Fricke, H.S.G. (1986). Simple gas-liquid chromatographic method for the simultaneous determination of fatty acids and alcohols in wax esters of marine organisms. J. Chromatogr., 361, 263-268. https://doi.org/10.1016/S0021-9673(01)86914-4

Leite, G.B., Abdelaziz, A.E.M., \& Hallenbeck, P.C. (2013) Algal biofuels: challenges and opportunities. Bioresour. Technol., 145, 134-141. https://doi.org/10.1016/j.biortech.2013 .02 .007

Li, T., Zheng, Y., Yu, L., \& Chen, Z. (2013). High productivity cultivation of a heat-resistant microalga Chlorella sorokiniana for biofuel production. Bioresour.Technol. 131, 60-67. https://doi.org/10.1016/j.biortech.2012.11.121

Liu, Z.Y., Wang, G.C., \& Zhou, B.C. (2008). Effect of iron on growth and lipid accumulation in Chlorella vulgaris. Bioresour.Technol., 99, 4717-4722. https://doi.org/10.1016/j.biort ech.2007.09.073 
Lu, Y., \& Xu, Y. (2015). Phytohormones in microalgae: a new opportunity for microalgal biotechnology. Trend Plant Sci., 20(5), 273-282. http://dx.doi.org/10.1016/j.tplants.2015 .01 .0

Mata, T.M., Martins, A.A., \& Caetano, N.S. (2010). Microalgae for biodiesel production and other applications: a review. Renew Sust. Energ. Rev., 14, 217-232. https://doi.org/10.1016/j.rser.2009.07.020

Mekhalfi, M., Amara, S., Robert, S., Carriere, F., \& Gontero, B. (2014). Effect of environmental conditions on various enzyme activities and triacylglycerol contents in cultures of the freshwater diatom, Asterionella formosa (Bacillariophyceae). Biochimie., 101, 21-30. https://doi.org/10.1016/j.biochi.2013.12.004

Minhas, A.K., Hodgson, P., Barrow, C.J., Sashidhar, B., \& Adholeya, A. (2016) The isolation and identification of new microalgal strains producing oil and carotenoid simultaneously with biofuel potential. Bioresour. Technol., 211, 556-565. https://doi.org/10.1016/j.biortech.2016.03.121

Nakajima, M., Shimada, A., Takashi, Y., Kim, Y.C., Park, S.H., Ueguchi-Tanaka, M., Suzuki, H., Katoh, E., Iuchi, S., Kobayashi, M., Maeda, T., Matsuoka, M., \& Yamaguchi, I. (2006). Identification and characterization of Arabidopsis gibberellin receptors. Plant J., 46, 880-889. https://doi.org/10.1111/j.1365-313X.2006.02748.x

Park, W.K., Yoo, G., Moon, M., Kim, C.W., Choi, Y.E., \& Yang, J.W. (2013). Phytohormone supplemantion significantly increases growth of Chlamydomonas reinhardtii cultivated for biodiesel production. Appl. Biochem. Biotechnol 17(1), 1128-1142. https://doi.org/10.1007/s12010-013-0386-9

Radley, M. (1961). Gibberellin-like substances in plants. Nature (Lond.). 191, 684-685.

Ren, H.Y., Liu, B.F., Kong, F., \& Zhao, L. (2014). Enhanced lipid accumulation of green microalga Scenedesmus sp. By metal ions and EDTA addition. Bioresour. Technol., 169, 763-767. https://doi.org/10.1016/j.biortech.2014.06.062

Rodolfi, L., Chini Zittelli, G., Bassi, N., Padovani, G., Biondi, N., Bonini, G., \& Tredici, M. (2009) Microalgae for oil: strain selection, induction of lipid synthesis and outdoor mass cultivation in a low-cost photobioreactor. Biotechnol. Bioeng., 102, 100-112. https://doi.org/10.1002/bit.22033

Sasaki, A., Ithoh, H., Gomi, K., Ueguchi-Tanaka, M., Ishiyama, K., Kobayashi, M., Jeong, D.H., An, G., Kitano, H., Ashikari, M., \& Matsuoka, M. (2003). Accumulation of phosphorylated repressor for gibberellin signaling in an F-box mutant. Science, 299(5614), 1896-1898. https://doi.org/10.1126/science.1081077

Solovchenko, A.E., Khozin-Goldberg, I., Didi-Cohen, S., Cohen, Z., \& Merzlyak, M.N. (2008). Effects of light intensity and nitrogen starvation on growth, total fatty acids and arachidonic acid in the green microalga Parietochloris incisa. J. Appl. Phycol., 20, 245251. https://doi.org/10.1007/s10811-007-9233-0

Sreekumar, N., Chennattussery, A.J., Mariya, A., \& Selvaraju, N. (2018). Anaerobic digester sludge as nutrient source for culturing of microalgae for economic biodiesel production Int. J. Environ. Sci. Technol., 15, 2607-2614. https://doi.org/10.1007/s13762-017-1491-z

Tyler, L., Thomas, S.G., Hu, J., Dill, A., Alonso, J.M., Ecker, J.R., \& Sun, T. (2004). DELLA proteins and Gibberellin-regulated seed germination and floral development in Arabidopsis. Plant Physiol., 135, 1008-1019. https://doi.org/10.1104/pp.104.039578

Yu, X.J., Sun, J., Sun, Y.Q., Zheng, J.Y., \& Wang, Z. (2016). Metabolomics analysis of phytohormone gibberellin improving lipid and DHA accumulation in Aurantiochytrium sp. Biochem. Eng. J., 112, 258-268. https://doi.org/10.1016/j.bej.2016.05.002

Zhu, S., Huang, W., Xu, J., Wang, Z., Xu, J., \& Yuan, Z. (2014). Metabolic changes of starch and lipid triggered by nitrogen starvation in the microalga Chlorella zofingiensis. Bioresour Technol., 152, 292-298. https://doi.org/10.1016/j.biortech.2013.10.092 